\title{
Human Trafficking, the Japanese Commercial \\ Sex Industry, and the Yakuza:
}

\section{Recommendations for the Japanese Government}


Amanda Jones is a second-year MPP candidate at the Gerald R. Ford School of Public Policy at the University of Michigan. While at the Ford School, Amanda has primarily focused on topics related to international relations, such as human rights, intrastate conflict, and transnational security threats. Last summer, she interned with the Government Accountability Office (GAO) in the Acquisitions and Sourcing Management division. While working at the GAO, Amanda worked on projects related to space security and the oversight of small business contracts for the development of space equipment (i.e. satellites, GPS software, etc.). Prior to joining the Ford School, Amanda taught English in Japan and worked as a consultant in Washington, DC. She graduated from Washington and Lee University in 2005 with a degree in Psychology.

Human trafficking is a global issue that is only recently being recognized with global action. The United Nations' Protocol to Prevent, Suppress and Punish Trafficking in Persons, Especially Women and Children (UNTIP), the first global initiative of its kind, entered into force in 2003. This protocol defined human trafficking in order to set an international standard for the criminalization and prosecution of trading in persons.

Both the UN and the U.S. Department of State conduct global reviews of state actions to prevent human trafficking. Both reports indicate that human trafficking, especially that related to sexual exploitation, continues to be an issue in Japan. Their reports indicate that Japan implemented some of the policies required by UNTIP and that it has the resources with which to carry out these policies, but the reports suggest that Japanese officials lack the will to carry out these policy initiatives to combat human trafficking. This lack of will by government officials appears to be related to three key factors:

-The demand for sex by Japanese citizens

- The prevalence of sex within the Japanese culture

-The level to which the yakuza, gate-keepers to the commercial sex industry, are engrained in Japanese society
The yakuza worked with the Japanese government during World War II to provide Imperial soldiers with "comfort women." From there, the yakuza expanded into sex tourism, human trafficking of women to Japan, pornographic enterprises, etc. in addition to gambling businesses and the trafficking of drugs and weapons. The yakuza developed working relationships with other organized crime syndicates abroad to globalize their network and their legitimate and illegitimate businesses. The influence of the yakuza reaches almost every island in Japan, and the yakuza continues to be relatively accepted in Japan.

Upon visiting Japan, tourists are bombarded by bright lights and advertisements, many of which advertise for "massage parlors" or call girl services. Often, these shops serve as fronts for large-scale prostitution rings. The Japanese population supports thousands of these "shops", highlighting the high level of demand for the commercial sex industry in Japan.

To decrease human trafficking in Japan, government officials should implement policies aimed at decreasing demand for the commercial sex industry, dismantling the yakuza, increasing support for the 
identification of victims, and developing a regional partnership against human trafficking.

\section{A Global Issue: Human Trafficking}

Human trafficking is a criminal act that results in a loss of an individual's human rights, increases global health risks such as HIV/AIDS, and promotes the growth of organized crime. The UN defines human trafficking as:

"the recruitment, transportation, transfer, harboring, or receipt of persons, by means of the threat or use of force or other forms of coercion, of abduction, of fraud, of deception, of the abuse of power or of a position of vulnerability or of the giving or receiving of payments or benefits to achieve the consent of a person having control over another person, for the purpose of exploitation."1

Exploitation may include forced labor, sex slavery, domestic servitude, forced marriage, organ removal, ritual killings, and the use of children for begging and warfare. The definition for human trafficking applies to the exploitation of people domestically, regionally, and/or globally.

Although human trafficking has existed for centuries, the demand for the criminalization of human trafficking did not gain widespread support until the late 1990's. In 1999, the U.S. and Argentina presented a proposal to the United Nations for a protocol against human trafficking. The UN adopted the UN Convention against Transnational Organized Crime in November of 2000 and the affiliated UN Protocol to Prevent, Suppress and Punish Trafficking in Persons, Especially Women and Children (UNTIP) came into force in December of 2003. The U.S. Department of State began researching global human trafficking trends in 2000 and has since released eight comprehensive reports on the subject. The UN released their first global human trafficking report and launched a global awareness campaign in February of 2009.

As of November 2008, sixty-three percent of the 155 countries reviewed by the
UN had passed laws against human trafficking. An additional sixteen percent of countries surveyed passed anti-trafficking laws covering some aspects of the UNTIP. Additionally, the number of countries implementing UNTIP has doubled in the last few years from 54 . Despite these new protocols, though, the UN believes that human trafficking increased over the last year.

The exact number of humans trafficked annually is unknown, but the U.S. Department of State estimates that 800,000 people are trafficked across borders each year (this figure does not include domestic trafficking of persons); eighty percent of those trafficked are women and girls and up to fifty percent of victims are minors. ${ }^{2}$ Seventy-nine percent of human trafficking is conducted for the purposes of sexual exploitation. ${ }^{3}$

\section{History of Human Trafficking for Sexual Exploitation in Japan}

The issue of human trafficking for the purpose of sexual exploitation is nothing new to the people of Japan. The commercial sex industry has flourished in Japan since before World War II. During World War II, the yakuza, an organized crime syndicate, worked in conjunction with the Japanese government to provide sex slaves or "comfort women" to the members of the Imperial Army. The majority of these "comfort women" were exported from South Korea and other Asian countries after being attacked by the Japanese army. ${ }^{4}$ After World War II, the yakuza operated brothels for American servicemen to utilize throughout the U.S. occupancy. ${ }^{5}$

To this day, the Japanese government refuses to acknowledge the criminal activity of human trafficking during and after World War II. Officials claim that women volunteered to provide these services to support their country in a nationalistic endeavor to protect the interests of Japan, but neglect to mention that the majority of the women "offering" their services were Korean, not Japanese. The Japanese government's unwillingness to 
accept responsibility for these crimes against women continues to affect the perception of prostitution and the sex industry in Japan today.

\section{The Yakuza and Human Trafficking:}

After helping the Japanese government procure "comfort women" for Japanese and then American soldiers, the yakuza continued to develop the commercial sex industry in Japan. The 1970s and 1980s proved to be a prosperous time for Japan and the yakuza. Towards the end of the 1960s, the tourism industry exploded as Japanese citizens earned larger incomes and a strong yen made travel abroad relatively inexpensive. Tourism was not utilized to strengthen cultural education, though. Rather, Japanese men lined up at airports to experience wild weekends abroad with an itinerary focused on sex parties. Although the yakuza did not invent sex tourism, they capitalized on this new tourism frenzy by organizing large-scale sex tours throughout East Asia.



Many kisaeng, like those shown above, became known as prostitutes in the 1970s.

The yakuza first exploited this new industry in Taiwan and then Korea. In Korea, they organized trips to kisaeng parties. Kisaeng is a Korean word traditionally associated with female entertainers, very similar to Japanese geisha, but with the influx of tourists these women simply became known as prostitutes. By the end of the 1970s more than 650,000
Japanese citizens visited Korea annually with eighty percent of visitors listing kisaeng as the primary focus of their trip. ${ }^{6}$ Sex tourism became so popular that major airlines such as Japan Air Lines listed kisaeng parties amongst the recommended tourist activities in their guidebooks for Korea. ${ }^{7}$

During the 1970s the yakuza expanded the sex tourism industry to Thailand and the Philippines where many of the sex workers were sold into sex slavery by their poor families. The Yakuza did not control the industry in these countries; instead they worked with local gang members to bribe local village leaders to convince families to sell daughters into the sex industry. The yakuza also financed many of the clubs in which Japanese men frequented in these foreign countries and led many of the sex tours as guides to the best "sex spots."

In the early 1980s sex tourism began to receive negative attention. Protesting women's groups popped up throughout Japan and pressured the Prime Minister to put a halt to sex tourism. Sex tourism decreased but the overall demand for the commercial sex industry did not; therefore, the yakuza changed tactics and began to import foreign women so Japanese men wouldn't have to risk traveling abroad for sex. Japanese men continue to travel abroad for sex tourism (particularly for sex with children), ${ }^{8}$ but the yakuza focuses their efforts on importing foreign women.

\section{Response to Human Trafficking by Japanese Officials:}

Japan has not ratified the United Nations' Protocol to Prevent, Suppress and Punish Trafficking in Persons (UNTIP). ${ }^{9}$ Although several news stories highlighted the plight of foreign sex slaves in Japan throughout the 1990's, the Japanese government did little to decrease human trafficking until 2004. In 2004 the U.S. Department of State placed Japan on the "Tier 2 Watch List"10 which harmed Japan's image as a safe and relatively crime free country and motivated the Japanese government to act. 
To counteract this negative media attention, Japanese officials created and implemented a National Plan of Action to combat human trafficking in 2004 and in 2005 introduced the offence of buying and selling human beings. The government also defined trafficking in persons in Article 2 of the Immigration Control Act of 2006, criminalizing all forms of exploitation defined in Article 3 of the UNTIP. In order to prevent the human trafficking of sex workers, the Japanese government distributed 500,000 brochures throughout the country concerning the traumas faced by trafficked persons and information on how to receive assistance; distributed 25,000 trafficking awareness posters to police stations, foreign embassies, and consulates; and donated $\$ 79,000$ to a Thai NGO for the construction of a dormitory for vulnerable Thai citizens in Japan.

\section{"In 2004 the U.S. Department of State placed Japan on the 'Tier 2 Watch List' which harmed Japan's image as a safe and relatively crime free country and motivated the Japanese government to act."}

The Japanese government provides various services to victims of human trafficking in accordance with UNTIP, such as legal protection and legal services, temporary stay programs, medical and psychological support, housing and shelter, and repatriation assistance. The government created the Women's Consulting Office to aid battered women in the 1990s but it now also serves as a refuge for trafficked women. As of 2006 the Women's Consulting Office had 47 offices throughout the country with the ability to house 720 women at any point in time.

\section{Analysis}

\section{Demand for the Commercial Sex Industry:}

Sex has played a prominent role in the Japanese culture for centuries. Shunga, erotic art and pornographic paintings and woodblock prints, dates back to the Edo Period of the $17^{\text {th }}-19^{\text {th }}$ centuries. Although pornography has changed greatly since that time, it is still a mainstay in Japanese culture. Hentai Anime is a type of pornographic comic originally created in Japan that is now exported around the world; it is estimated to net twenty million dollars in sales in the U.S. alone. In addition, there are over 1,000 companies producing more than thirty new legal and illegal adult videos per day in Japan. ${ }^{11}$ These videos are sold in stores and in vending machines. The production companies operate "adult video acting schools" for young women and many of these actresses have online fan clubs. Although it is illegal to produce child pornography in Japan, it is not illegal for Japanese citizens to own or possess child pornography. Many critics of child pornography relate the acceptance of child pornography to the continued demand for sexual exploitation of children by Japanese men. ${ }^{12}$

"Massage parlors" typically serve as fronts for the commercial sex industry. The yakuza are responsible for opening the first "massage parlors" throughout Japan and continue to operation the majority of these shops. This industry has expanded to include soaplands, bath houses where men receive personal bath experiences with a beautiful young helper; fashion-health delivery services, an escort home delivery service; image clubs, a place where men can live out their fantasies with their choice of women in themed rooms; and pink salons, semi-public pubs where men can receive oral sex while enjoying sake or beer. These shops have been able to subvert the anti-prostitution laws by limiting their advertising to the non-intercourse services offered.

Surveys conducted throughout Japan indicate that over fifty percent of men have paid for sex and seventy-five percent of junior and high school girls have been solicited by middle aged men. ${ }^{13}$ These survey results and the prevalence of sex-related shops indicate 




Signboards promote sex-related services at a red light district in Shinjuku, Tokyo.

that the demand for sex is directly integrated within the Japanese culture, and has been for centuries. One signal that Japanese women are pushing for a change in this culture is the demand for female only subway cars during rush hour. The groping of women on railways is a common practice for chikan, Japanese for pervert. Over 2,000 arrests were made for the molestation of women on railways last year alone, but experts believe this number represents only a tiny fraction of those women accosted on public transit annually. ${ }^{14}$

\section{Yakuza - A Mainstay in Japanese Culture:}

The yakuza enjoy a relative acceptance by the people, national government, and local police forces of Japan. For decades the yakuza have offered services that even the national government approved, albeit not publicly. Japan places a cap on the number of lawyers allowed to practice in the country and the government is known for its reluctance to litigate. In Japan, there is approximately one lawyer per 8,500 people, in the UK there is one lawyer per 900 people, and in the U.S. there is one lawyer per 400 people. ${ }^{15}$ Because of the lack of lawyers in Japan, it is very expensive to file civil suits in Japan. Some members of the yakuza have become known as urashakai no bengoshi, lawyers from the dark side of society, and are increasingly used by citizens to solve disputes. David Kaplan and Alec Dubro unearthed a poll from 1993 which found that " 23 percent of men and 17 percent of women believed that hiring gangsters to collect money, obtain contracts, or settle disputes by threatening violence is 'not bad' or 'can't be helped."'16

In addition, the yakuza and the police force have had a relatively peaceful coexistence and many times are on a first name basis with one another. Many attribute the generally low violent crime rates to the yakuza because organized crime in Japan is less violent than unorganized crime. For instance, if an individual hoodlum commits a violent crime in a neighborhood "owned" by a yakuza affiliate, the yakuza are likely to reach and punish this individual before the police even hear about the crime. This co-existence is also sponsored by bribes and pay-offs. To appear as though the police force is above corruption, they periodically stage large scale crackdowns on the gangs. These "busts" are generally preorchestrated and serve as publicity stunts for the newspapers.

\section{The Yakuza Connection Abroad:}

Between 2005 and 2006, the Japanese National Police Agency (NPA) found that forty percent of identified human trafficking victims were Filipino, thirty-three percent were Indonesian, fourteen percent were Thai, eight percent were Chinese/Taiwanese, and three percent were Russian or East European. ${ }^{17}$ The yakuza has very strong ties with Filipino business leaders and bureaucrats, with various gangs throughout the Golden Triangle (Burma, Laos, and Thailand), the Chinese Triads, and the Russian mob; the nationalities of identified victims provide ample evidence for these connections.

Due to these various gang connections of the yakuza, breaking the chain for human trafficking would prove to beincredibly difficult. Once one connection or source was severed another connection in another part of the world would surely be created as the yakuza's network spans the globe. Any approach to disrupting the yakuza's illegal global activities would have to be performed in a multilateral forum to ensure governments around the world would help clamp down on organized 
crime simultaneously. Unfortunately, many governments of developing countries have few resources with which to crack down on organized crime.

\section{Japanese Response to Human Trafficking- Is it Working?}

After being placed on the Human Trafficking "Tier 2 Watch List" by the U.S. Department of State, Japanese officials energetically passed several new legislative policies aimed at cracking down on human trafficking. After 2005, though, the Japanese government again awarded less attention to the plight of victims being trafficked into the country for the commercial sex industry. The number of victims identified decreased two years in a row. The number of victims reaching out to NGOs and help hotlines indicates that the actual number of trafficked victims is larger than the statistics kept by the Japanese government, though; thus, it is unlikely that the number of humans trafficked into Japan decreased in the last few years but rather suggests that the commercial sex industry has most likely moved underground.

In addition, the number of prosecutions for human trafficking decreased in 2007 from seventeen in 2006 to eleven in 2007. Of the twelve offenders convicted in the eleven prosecuted cases in 2007, seven of those convicted received sentences between two to four years and five received suspended sentences. In comparison, those convicted of human trafficking in the U.S. receive a minimum of ten years in prison with the possibility of being sentenced to life in prison if convicted of organizing the human trafficking operations.

Although Japan offers many services to victims of human trafficking, they don't explicitly advertise these services. The NPA lacks language experts to help translate foreign victims' testimony and often foreign victims are not educated on their rights to legal aid, temporary stay programs, and repatriation assistance. Against protocol, Japanese officials repatriated 16 of 43 victims in 2007 without referring them to the International Organization for Migration (IOM) for risk assessment and formal repatriation. Many of these women may have become victims of reprisals in their own country because the Japanese officials did not appropriately gauge the risk of sending them back to their home countries. Additionally, because of the yakuza's continued ability to infiltrate the police forces, many victims are scared to approach the police for help for fear of being returned to their handler.

\section{Policies Utilized to Combat the Sexual Exploitation of Trafficked Humans in Other Countries:}

Trafficking in persons for the purpose of sexual exploitation continues to be a problem in almost every country in the world. In their 2008 report on human trafficking, the U.S. Department of State recognized the contributions of Madagascar, Brazil, and France for their national campaigns to increase awareness about human trafficking. ${ }^{18}$ The government of Madagascar distributed a film highlighting the dangers of child sex tourism to schools throughout the country in hopes of educating the youth about various scams human traffickers may utilize to ensnare them. With a similar goal in mind, the government of Brazil implemented a national awareness campaign which described the crimes and punishments associated with human trafficking and provided contact information for those seeking help. Brazil's national awareness campaign was broadcasted in several languages so that vulnerable foreigners could access the information. France's state controlled airline, Air France, shows inflight videos that define the crime of human trafficking and the associated penalties. These campaigns educate large groups of people about the dangers of human trafficking.

In 1999, Sweden criminalized the purchase and brokering of sexual services and decriminalized the selling of sexual services with the hope of decreasing human trafficking. This was the first policy of its kind and was 
not warmly received in Sweden or elsewhere. Many feared that prostitution would move underground or that those women who knowingly offered these services would be subject to higher rates of sexually transmitted diseases, abuse, etc. Initially, the policy focused solely on the penalties associated with the new crime but did little to support those women involved in prostitution. More recently, the government began to offer services to help prostitutes emerge from the commercial sex industry, such as drug rehabilitation treatment programs, work training programs, and other health and psychological services. ${ }^{19}$

Almost ten years after the implementation of this policy, evidence suggests the policy has been extremely effective in lowering human trafficking and overall prostitution rates. In 2008 Swedish police estimated that $400-600$ people were trafficked into the country annually, whereas an estimated 10,000-15,000 women were trafficked into neighboring Finland. The Swedish police also estimate that the number of active prostitutes in Stockholm dropped to approximately 105-130; the estimated number of active prostitutes in Oslo reaches 5,000. ${ }^{20}$

More importantly, though, the perception of the crime by Swedish nationals has changed drastically over the past ten years. In 1996, three years before the ban was implemented, only thirty percent of the population felt it was wrong to pay for sex. A similar survey conducted in 2008 indicated that seventy percent of respondents favored maintaining the ban criminalizing the payment for sex. ${ }^{21}$ These cases signify a shift in the "norm" with regards to attitudes towards the payment for sex, a changing "norm" which ultimately decreases the overall demand for the commercial sex industry.

\section{Recommendations}

In order to decrease human trafficking in Japan, government officials must take a multi-dimensional approach to the problem, and approach that includes the signing of the UNTIP, forcing a shift in the perception of paying for sex, dismantling the strong organized crime networks, an increase in funding for operations to identify trafficking victims, and a cooperative regional agreement with members of the Association of Southeast Asian Nations (ASEAN).

\section{Sign the UNTIP:}

By signing the UNTIP Japanese officials prove, to the world and to their own citizens, they recognize that human trafficking is a global issue for which every country is responsible for remedying. By accepting responsibility for combating national and international human trafficking, Japanese officials will set a standard in Japan and help force a shift in beliefs concerning the commercial sex industry.

\section{Force A Shift in the "Norm":}

As the Sweden case indicates, it is possible to alter the perceptions of a nation in a relatively short time period. The demand for the commercial sex industry remains high throughout Japan and the relative acceptance of organized crime (the yakuza), the primary instigator behind human trafficking in Japan, induces an environment in which human trafficking thrives. In order to destroy this environment, the Japanese government must prove they have the political will to combat human trafficking throughout Japan. The following actions should be taken to decrease demand for the commercial sex industry:

\section{Follow Sweden's lead -}

Criminalize the act of paying to have sex with trafficked women and children. This policy would need to be implemented in conjunction with increased funding for support services, such as health and psychological services, for prostitutes and victims of human trafficking. This policy idea is gaining prominence in the Netherlands, where prostitution is currently legal, as there is little evidence to indicate that legalization of prostitution has decreased crime as originally expected. ${ }^{22}$ 


\section{Increase prosecutions-}

Japan currently has multiple laws addressing human trafficking (albeit not an all inclusive, comprehensive anti-trafficking law). One of these laws allows the Japanese government to prosecute Japanese nationals for crimes committed overseas, but this law has not been enacted since 2005. According to the U.S. Department of State, Japanese men continue to travel abroad to have sex with children and so violate the Japanese law protecting minors from abuse. If criminal activities such as this were prosecuted at a higher rate, it may cause a shift in behavior.

Criminalize possession of child porn-

Although it is illegal to produce child pornography in Japan, it is not illegal to possess it. By decreasing access to child pornography, overall demand for the sexual exploitation of children will decrease.

Increase punishments for human trafficking-

The current Japanese laws against the buying and selling of persons limits prison terms to ten years. By increasing the punishment associated with human trafficking, the Japanese government can increase the stigma associated with the commercial sex industry.

\section{Dismantle the Yakuza:}

Although the yakuza has lost a great deal of prominence amongst the people of Japan over the last decade, their presence and the services they provide continue to be engrained in the Japanese culture. The Japanese government must diminish the role of the yakuza in Japanese society before they can dismantle the organization.

\section{Implement a "strike force"-}

To combat the U.S. Mafia, the United States established a national investigative unit, the United States Organized Crime Strike Force, to inspect organized criminal activities and collect evidence to prosecute high ranking members of the mafia families. This body worked with other national and local law enforcement agencies to bring members of organized crime syndicates to justice. Because the yakuza ranks as one of the top four most complex criminal organizations in the world, ${ }^{23}$ the Japanese government should create a specialized investigative unit within the NPA to address organized crime.

Create a zero tolerance policy for corruption-

The Japanese government must alter perceptions concerning the acceptance of the yakuza. The government should crackdown on police members and government officials who accept bribes from yakuza members to distill any beliefs that the government coexists peacefully with the yakuza.

Crack-down on suspected commercial sex businesses-

Many commercial sex businesses advertising oral sex or call girl services pose as fronts for full scale prostitution rings. The Japanese police forces must monitor these businesses more closely to detect and break-up more prostitution rings and collect evidence against top yakuza members. This increased surveillance may also increase the number of victims identified.

\section{Increase Funding for the Identification of Victims of Human Trafficking:}

Japanese police forces require additional training to better equip their members with the knowledge necessary to unearth non-mainstream commercial sex businesses in order to identify foreign and domestic victims of human trafficking. In addition, further training may help police forces track the yakuza money trail which may enable the government to more closely monitor new or changing business structures of the yakuza.

Increase training for investigative practices concerning the commercial sex industry-

With the introduction of more stringent laws aimed at decreasing human trafficking in 2005, many fear the commercial sex industry has gone underground. The decreased number of prosecutions and the number of victims identified since 2005 may be indicative of this movement underground. 


\section{Work with ASEAN to Create a Regional Human Trafficking Policy:}

The flow of human beings to Japan is a regional issue. More than fifty percent of those trafficked in and within Japan are foreigners, ${ }^{24}$ and of those the large majority comes from developing countries in Asia. To decrease human trafficking in Japan and throughout the region, Japan should work with other members of ASEAN to create a regional, comprehensive human trafficking policy.

\section{A Multi-Lateral Approach-}

The European Union created the Council of Europe Convention on Action against Trafficking in Human Beings in December of 2008 to combat the increase in human trafficking throughout the EU.25 Although ASEAN member countries are not as closely linked as those of the EU, they can simulate the actions taken by the EU in implementing a regional policy targeting human trafficking.

\section{Japan Must Lead the Way-}

Throughout Asia, the primary concern will be the need to combat poverty as poverty serves as a catalyst for many of the schemes the yakuza and other gangs utilize to deceptively recruit sex workers. Japan will need to offer funding to many of these countries (particularly the Philippines, Thailand, and Indonesia) for national campaigns aimed at educating the population about tactics utilized to trick citizens into sex slavery.

\section{Regional Action Against Organized Crime-}

Japan should also offer funding for increased training of immigration officials and police forces in ASEAN countries so that they may be better trained to identify potential victims of human trafficking. In addition to funding, Japan should provide better intelligence to other countries concerning the identities of yakuza members and international gang connections so that police forces in foreign countries can intercept criminals abroad. With more funding, training, and better intelligence per Japan, ASEAN can attempt to weaken links between the yakuza and other regional organized crime syndicates.

\section{Endnotes}

United Nations, "Protocol to Prevent, Suppress and Punish Trafficking in Persons, Especially Women and Children," http://www.uncjin.org/Documents/Conventions/ dcatoc/final_documents_2/convention_\%20traff_eng.pdf.

U.S. Department of State, "Trafficking in Persons Report 2008," Introduction, pgs 1-53, June 2008, http://www.state.gov/documents/organization/105655.pdf. UNODC, "Global Report on Trafficking in Persons," February 2009, http://www.unodc.org/documents/Global_Report_on_TIP.pdf.

Rollie Lal, “Chapter 10: Japanese Trafficking and Smuggling," in Transnational Threats: Smuggling and Trafficking in Arms, Drugs, and Human Life, edited by Kimberly Thachuk. 2007. Westport, CT: Greenwood Publishing Group, Inc.

Roth, Mitchell P. Organized Crime. 2010. Upper Saddle River, NJ: Pearson Education, Inc.

Kaplan, David E. \& Dubro, Alec. Yakuza: Japan's Criminal Underworld. 2003. Berkeley, CA: University of California Press.

Ibid

U.S. Department of State, "Trafficking in Persons Report 2008," Introduction, pgs 1-53, June 2008, http://www.state.gov/documents/organization/105655.pdf. Ibid

10 Rollie Lal, "Chapter 10: Japanese Trafficking and Smuggling," in Transnational Threats: Smuggling and Trafficking in Arms, Drugs, and Human Life, edited by Kimberly Thachuk 2007. Westport, CT: Greenwood Publishing Group, Inc.

1 Japan Visitor, "Sex Glossary," http://www.japanvisitor.com/index.php?cID=365\&pID=387\&cName=Sex\&pName=culture-sex-glossary.

12 U.S. Department of State, "Trafficking in Persons Report 2008," Introduction, pgs 1-53, June 2008, http://www.state.gov/documents/organization/105655.pdf.

13 Japan Visitor, "Sex Glossary," http://www.japanvisitor.com/index.php?cID=365\&pID=387\&cName=Sex\&pName=culture-sex-glossary.

14 Ibid

15 Kaplan, David E. \& Dubro, Alec. Yakuza: Japan's Criminal Underworld. 2003. Berkeley, CA: University of California Press.

16 Ibid

17 UNODC, "Global Report on Trafficking in Persons," February 2009, http://www.unodc.org/documents/Global_Report_on_TIP.pdf.

18 U.S. Department of State, "Trafficking in Persons Report 2008," Introduction, pgs 1-53, June 2008, http://www.state.gov/documents/organization/105655.pdf.

19 humantrafficking.org, "Prostitution Ban Huge Success in Sweden," 30 January 2008, http://www.humantrafficking.org/updates/838.

20 lbid

21 Gregg Bucken-Knapp, "Swedish Attitudes Towards the Purchase of Sexual Services," Nordic Prostitution Policy Reform, 9 February 2009, http://nppr.se/2009/02/09/ swedish-attitudes-towards-the-purchase-of-sexual-services/ (Accessed 15 April, 2009).

22 BBC, "Europe and NZ Poles Apart on Sex Trade," 18 March 2009, http://news.bbc.co.uk/2/hi/europe/7933973.stm.

23 PBS, “Wide Angle -

Business of Human Trafficking: Criminal Groups," 23 September 2003, http://www.pbs.org/wnet/wideangle/episodes/dying-to-leave/business-of-human-trafficking/ criminal-groups/1423/.

24 UNODC, "Global Report on Trafficking in Persons," February 2009, http://www.unodc.org/documents/Global_Report_on_TIP.pdf.

25 Council of Europe, "Action Against Trafficking in Human Persons," http://www.coe.int/t/dghl/monitoring/trafficking/Docs/Convntn/FSConv_en.asp\#TopOfPage. Photos Courtsey of: 